\title{
Airborne Fungi in Indoor Hospital Environments
}

\section{Jean Phellipe Marques do Nascimento ${ }^{1}$, Ana Maria Queijeiro López ${ }^{2}$, Mykaella Andrade de Araújo ${ }^{3}$, Lucas Anhezini de Araujo ${ }^{4}$ and Eurípedes Alves da Silva Filho ${ }^{1 *}$}

${ }^{1}$ Federal University of Alagoas, Institute of Biological Sciences and Health, Laboratory of Genetic and Applied Microbiology. Maceió - AL, Brazil

${ }^{2}$ Federal University of Alagoas, Institute of Chemistry and Biotechnology, Laboratory of Biochemistry of Parasitism and Environmental Microbiology. Maceió - AL, Brazil

${ }^{3}$ Federal University of Alagoas, Institute of Biological Sciences and Health, Laboratory of Cell and Molecular Biology. Maceió - AL, Brazil

${ }^{4}$ Federal University of Alagoas, Institute of Biological Sciences and Health, Laboratory of Developmental Biology of Drosophila. Maceió - AL, Brazil

*Corresponding author

\section{A B S T R A C T}

\section{Keywords}

Airborne fungi, Air quality, Bioaerosol, Allergens

Article Info

Accepted:

17 December 2018

Available Online:

10 January 2019
The relationship between air quality and human health has been indisputably evidenced in the literature. In indoor environments this quality can be influenced by the presence of microorganisms. In these places, fungi find every favorable condition for their growth and development. Factors such as temperature, relative humidity, infiltrations in the building structure and availability of nutrients may be associated with the success of the presence of fungi in indoor air. Fungi can put at risk the health of occupants of a given environment, favoring the emergence of allergies and serious infections. In the hospital context, patients, professionals and visitors can have their health compromised by the presence of airborne fungi that can cause serious damage. Allergens produced by various species of fungi are known to affect susceptible people and are related to allergic diseases like asthma and rhinitis. In this review we highlight the participation of some fungi as one of the main indoor air contaminants and the risk of aerial exposure to these microorganisms in hospital environments.

\section{Introduction}

The activities we develop in our daily routine contribute to our long stay indoors. In these places the air that circulates is the result of a cooling process, which provides better wellbeing to those who are present. However, the quality of the air circulating in these environments can have a significant effect on the health of occupants and, instead of providing comfort, influence a situation of discomfort and even the emergence of diseases related to the environment (Sterling et al., 1991; Wolkoff, 2018). Buildings where the air quality is inadequate and the reflection of this inadequacy may cause direct effects on 
the health of workers or residents are thus referred to as "sick buildings", being involved in a condition called the Sick Building Syndrome (SBS).

Sick Building Syndrome (SBS) is a generic term that describes the situation in which the occupants of a given building experience nonspecific symptoms which relate directly to the time in which they develop their activities inside the building (Joshi, 2008; Ghaffarianhoseini et al., 2018). The precondition to classify a building as "sick" relates to the presence of pollutants in the air that circulates, resulting in the occupants being exposed to an environment of poor air quality. The symptoms experienced by the occupants of such sites are usually headaches, disturbances in the eye (irritation, pain, itching, constant tearing or dryness), nasal problems (nasal irritation, nasal cold or runny nose), drowsiness, fatigue, lack of concentration, colds, sore throats, backaches, cold extremities, tension, dry skin, dizziness, muscle aches, weakness, difficulty breathing and wheezing (Joshi, 2008; Schirmer et al., 2011). Indoor air quality in several different types of environments can be influenced by many factors, of which chemical and biological contaminants can significantly harm the health of exposed individuals.

Different chemical pollutants with various properties and different concentrations in the environment have been reported as compromising factors to the indoor air quality (WHO, 2010). Some of the major chemical pollutants detected in indoor air are carbon dioxide, inorganic gases, ozone and organic compounds (Luengas et al., 2015). Bessonneau and collaborators evaluated the chemical contamination of indoor air in a school hospital in France, the results showing compounds such as alcohols, esters and ketones as the most prevalent in the air samples analyzed. Additionally, aromatic hydrocarbons, aliphatic hydrocarbons, aldehydes and terpenes were also found in the samples (Bessonneau et al., 2013).

Biological pollutants that are often related to contamination of indoor air include: animal allergens (dust mites and certain proteins), pollen grains, bacteria, endotoxins, fungi and their spores, as well as mycotoxins, which are products of the secondary metabolism of many species of fungi (Luengas et al., 2015; Kim et al., 2017). The presence of biological agents such as bacteria, fungi and viruses in a particular environment and their interference in the quality of the air that circulates in these locations will significantly depend on the factors favoring growth and establishment of these species in the indoor environment. Temperature, moisture and nutrient availability are the major factors commonly related to their establishment (Haleem-Khan and Karuppayil, 2012; Nazaroff, 2013).

With respect to air quality in hospital settings, there are many concerns about the influence and effects that poor-quality air can cause in individuals that are exposed to it, especially patients whose hospital stay should be related to their evolution and recovery. For example, maintaining a well-ventilated space can be of great impact and significance in terms of indoor hospital air quality, since it results in the protection of visitors, health professionals and patients from the most diverse types of pollutants that circulate in the environment via aerial dispersion (Li et al., 2007).

When it comes to patients with immune system impairment, the risk of developing infections caused by spores or fungal fragments present in the air increases substantially. Measures that contribute to the reduction of microbiological contamination of the air in hospital environments represent an extreme value in the prevention of nosocomial infections of the most susceptible individuals 
(Gangneux et al., 2006), as inhalation of ambient air is one of the main routes of exposure to fungal pathogens (Peláez et al., 2012). Holý and collaborators (2015) carried out a study where they evaluated the microbial contamination of the indoor air collected in a Transplant Unit in a university hospital, as well as verifying the performance of an air filtration system against the observed contamination. The authors verified that the air filtration equipment was efficient to improve the air quality in the analyzed environment, particularly when they found very little evident microbial growth from the samples collected following the use of the filtration device. Since fungi can be considered one of the main contaminating microorganisms in indoor air (Quadros et al., 2009), the application of actions to monitor these microbial contaminants in the air and the role of these measures in the containment of certain diseases caused by these pathogens are noteworthy (Holý et al., 2015).

\section{Fungi in indoor air environments}

Indoor air environments represent one of the many places of occurrence and importance with regard to the presence of fungi. Their adaptive characteristics favor their global dispersion, allowing the survival of these microorganisms in several habitat types (Nevalainen et al., 2015; Coombs et al., 2018). Monitoring of airborne fungi has already been recorded in the 19th century (Maddox, 1870), as well as at the beginning of the second half of the 20th century. This initial research on the topic aimed to investigate concentrations of fungi in the outside air (Morrow et al., 1942; Hirst, 1952; Hamilton, 1959). Since the early days, researchers were aware of the relationship between the concentrations of fungal spores in outdoor air and their presence in indoor air, as well as the health risks of exposure to these spores in the air from both outdoor and indoor environments (Richards, 1954). The presence of fungi in hospital air was first demonstrated by Noble and Clayton (1963) and later in a study by Lidwell and Nobe (1975) that demonstrated the performance of airconditioning devices as a source of fungi for ambient air. The presence of fungi as contaminants or biocontaminants that affect indoor air quality has been widely discussed in the literature (Miller, 1992; Gorny et al., 2002; Dubey, 2011; Caillaud et al., 2018).

It is very clear today that most of the fungi present in indoor air come to these sites mainly through external air, which is an important source of biological contamination for indoor air (Lee et al., 2006; Crawford et al., 2015; Abassi and Samaei, 2018). Although external air contributes significantly to the composition and increase in the concentration of fungal spores in indoor air, this is not the only way indoor air contamination can occur. Domestic and everyday activities may have a considerable impact on the concentrations of spores in the air (Lehtonem and Reponem, 1993; Awad et al., 2018). Manipulation of organic material (firewood and potted plants), handling of bedding, dog and cat hair, human skin, hair and nails, as well as clothing and human occupation can positively influence the spores in the indoor air (Reponen et al., 1992; Pitkaranta et al., 2008).

The factors considered preponderant in influencing the presence and development of fungi in environments with indoor air are: humidity, temperature and nutrient availability (TANG et al., 2015). Baughman and Arens (1996) argue that building materials such as wood, cellulose, wallpaper, organic insulation materials, textiles, glues and paints may contain nutrients such as carbohydrates and proteins which serve the fungal growth very well. Still, according to these authors, materials such as concrete, metals, glass fibers, plastics and other synthetic products, 
although not readily used by fungi, can contain organic remains that serve as a source of nutrients. In general, the temperature and humidity values for indoor fungi growth may vary depending on the species considered. Indoor air environments usually have optimum temperature values for fungi growth, ranging from $10-35{ }^{\circ} \mathrm{C}$ (WHO, 2009). For relative humidity, values below $75 \%$ are reported as limiting for fungal growth in buildings (Rowan et al., 1999). The critical relative humidity conditions for microbiological growth in building materials were defined by Johansson and collaborators (2005), who established that depending on the group of materials (wood, concrete and others) the fungal growth could occur in values of minimum relative humidity of $75 \%$ and maximum of $95 \%$. Polizzi and collaborators (2011) analyzed the metabolic response of some species of fungi found in indoor air under different environmental conditions and found that temperatures of $25^{\circ} \mathrm{C}$ and $30{ }^{\circ} \mathrm{C}$, as well as values of relative humidity in the range of $97-100 \%$ were considered ideal conditions for the growth of Penicillium spp., Aspergillus spp. and Periconia spp. Fungal growth in building materials was observed at temperatures and relative humidity values of 5 ${ }^{\circ} \mathrm{C}$ to $91 \% \mathrm{RH}, 10{ }^{\circ} \mathrm{C}$ in $90-95 \% \mathrm{RH}, 20{ }^{\circ} \mathrm{C}$ in $86-90 \% \mathrm{RH}$, and $25{ }^{\circ} \mathrm{C}$ in $78-86 \% \mathrm{RH}$ (Nielsen et al., 2004).

Once present in the environment and compromising air quality, the determination of a limit value of fungal concentration that is not enough to cause health risks to exposed individuals would be extremely relevant. Nowadays, the existence of an international standard guide concerning the maximum acceptable levels and values of fungal bioaerosols related to good air quality in indoor environments has not been established. Rao et al., (1996) reviewed and compared the regulations and quantitative standards for fungi in existing indoor air environments and concluded that a better characterization of fungi sources for these sites as well as more data related to the effects of acute and chronic exposure to these pathogens could be of great assistance in the elaboration of a reliable standard document. According to the American Conference of Governmental Industrial Hygienists (ACGIH), the absence of data related to the exposure and response to concentrations of bioaerosols, as well as the non-availability of a standard collection method in analyses of fungal bioaerosols make it difficult to draw up a common standard (ACGIH 2009). A review containing some recommendations from governmental and private organizations about concentrations of fungi in the air can be found in the review published by Rao et al., (1996). At present, there is an establishment of values of acceptable concentrations for various fungal bioaerosols whose variation depends on the country in question. Table 1 describes some limiting concentrations for indoor fungi in some countries. For hospital environments, the World Health Organization has defined a maximum acceptable value of $50 \mathrm{CFU} / \mathrm{m}^{3}$ for fungi (WHO, 1988).

\section{Fungal bioaerosols in hospital environments}

Nosocomial infections represent a major challenge and concern for hospitals, especially due to the high costs that they generate and the consequences for public health (Scott 2009; Singh et al., 2018). It is estimated that 10 to $20 \%$ of hospital infections are due to airborne pathogens (Eickhoff, 1994; Dürmaz et al., 2005). In hospitals, the main source of microorganisms for ambient air is infected patients themselves (Hambraeus, 1988; Lemaire et al., 2018). Although this is true for many bacterial and viral pathogens, the main source of fungi in the air in hospital environments, however, is outdoor air (Beggs, 2003; Abassi and Samaei, 2018). The opening 
of doors, windows and even the inflow and outflow of the hospital may favor increased concentration of fungal spores in the indoor air. Human occupation in the hospital (professionals and visitors), materials brought in by the occupants (personal objects, food and fruit) are also sources of fungi for indoor air (Nuruka et al., 2014). Ventilation systems have also been considered as likely sources of fungal contamination of indoor air (Batterman and Burge, 1995; Ahearn et al., 2004; Sowiak et al., 2018).

Since the conditions of the hospital environment are related to comfort and wellbeing for human coexistence and in these environments there is considerable presence of pathogenic fungi, these same conditions can also act favoring substantially the colonization and establishment of many of these microorganisms. Conditions like heat, moisture, shade, substrate material (e.g. carpets, furniture and concrete), as well as the presence of food can allow the development and permanence of viable fungi in these locations for extended periods of time (Kowalski, 2012). Neely and Orloff (2001) investigated the growth of some fungi of medical importance in samples of tissues and plastic materials, both for hospital use, verifying that Aspergillus and Fusarium grew and remained viable in the analyzed samples, indicating the high capacity of hospital environments to provide suitable conditions for the development of these pathogens. Aspergillus fumigatus, a species commonly found in indoor air environments, has also been found to develop for long periods of time (more than 30 days) in hospital cloth samples (Koca et al., 2012).

Ventilation, heating and air-conditioning systems in hospital environments can provide a microenvironment that is highly conducive to fungus growth and favors the spread of many infectious agents such as fungi in buildings (Ahearn et al., 2004). High relative humidity or condensation of water inside surfaces or ducts, filters and collecting trays in ventilation systems can promote fungal growth, just as the accumulation of dust and dirt may contain compounds that provide important nutrients to the metabolism of these microorganisms (Nevalainen et al., 2015). The material composition of air filters combined with the presence of moisture in them can also act in favor of the development of many fungi (Kemp et al., 2001; Viegas et al., 2018). Fungal growth in air-conditioners have been reported in the literature (Li et al., 2010, 2012; Viegas et al., 2018) as well as the capacity of the air filters to retain bacteria and fungi in ventilation systems (Moritz et al., 2001; Aquino et al., 2018). The first research related to fungal contamination of filters used in hospital ventilation systems was made by Arnow et al., (1978). In the results, they could verify the growth of A. fumigatus in the analyzed filters as well as relate the observed growth to some cases of aspergillosis. Later, outbreaks of aspergillosis were associated with contamination of hospital air filters, as well as dust and carpet samples in the same environment (Arnow et al., 1991). Simmons et al., (1997) analyzed several types of air filters in seven hospitals in order to investigate their colonization by fungi. Species of the genera Aspergillus, Acremonium, Alternaria, Cladosporium and Penicillium, which are fungi frequently present in indoor environments, were also found in the samples analyzed.

Several species of filamentous fungi can be found in aerial contamination investigations in hospital settings. Hong et al., (1999) analyzed air samples from 83 hospital sites and verified that species of the genera Cladosporium, Penicillium, Aspergillus, and Alternaria were the most frequent isolated fungi. Research on fungi concentrations in the indoor air of a Pediatric Hospital Unit revealed that 
Cladosporium, Alternaria, Penicillium, Aspergillus and Acremonium were the most prevalent genera (Okten and Asan 2012). Quadros and collaborators (2009), when investigating aerial microbiological contamination of a neonatal ICU, an adult ICU and two operating rooms, found that Aspergillus and Penicillum were the most common fungal genera, although Cladosporium and Acremonium were also present at a lower frequency. Qudiesat and collaborators (2009) evaluated the quality of air as well as the amount of aerial microorganisms in two hospitals. They found that in both hospitals Aspergillus spp., Penicillium spp., Rhizopus spp. and Alternaria spp. were the air contaminant fungal species. The authors also verified that the concentration of fungi and bacteria in the air of both environments were influenced by human occupation (Qudiesat et al., 2009).

Major fungi in hospital interior environments and their chemical allergens

Although many species of fungi are found in studies on air quality analysis in hospital settings, only Aspergillus, Penicillium, Cladosporium, Alternaria and Fusarium will be highlighted. In addition, the allergens produced by these fungi, whose presence in the environment can immensely affect the health of the exposed individuals, will also be briefly addressed as they are responsible for worsening the health status of immuneimpaired patientes.

\section{Genus Aspergillus}

Species of the genus Aspergillus can be found in several environments, including indoor hospital environments (Kousha et al., 2011; Asif et al., 2018). Only few species are considered human pathogens (Paulussen et al., 2016), among which we can highlight Aspergillus fumigatus, Aspergillus flavus,
Aspergillus nidulans, Aspergillus terreus, and Aspergillus niger (Hedayati et al., 2007; Kwon-chung and Sugui 2013; Hachem et al., 2014; Vermeulen et al., 2014; Veraldi et al., 2016). Barrs and collaborators (2013) also reported Aspergillus felis as a causative agent of invasive aspergillosis in humans. A. fumigatus is undoubtedly the species with the greatest impact in terms of infection of individuals with impaired immune system, as well as in the etiology of diseases caused by fungi that are transported by air (Morenogonzález et al., 2016).

Air exposure to fungal material can significantly affect the health of individuals in a particular environment, especially in hospitals, where conditions favor nosocomial infections. Clinical manifestations caused by Aspergillus can be categorized into allergic reactions, chronic pulmonary aspergillosis and invasive aspergillosis (Paulussen et al., 2016).

The presence of Aspergillus in hospital environments has been well described in the literature. Holý et al., (2015) reported microbiological contamination of air by Aspergillus sydowii, Aspergillus versicolor and A. terreus in a Transplant Unit of a university hospital. Several sites of a Hospital in India were used for air collection in order to carry out a monitoring study of contamination by filamentous fungi. Out of all isolated fungi, the genus Aspergillus was the most frequent, and the species A. niger and A. flavus stood out as the main air contaminants in the analyzed sites (Kushawaha et al., 2015). Interestingly, both species are related to aspergillosis and superficial infections in humans. In their study, Martins-Diniz and collaborators (2005) showed the presence of Aspergillus in the samples analyzed, which may compromise the recovery of patients, especially those immunologically impaired. The occurrence of $A$. fumigatus and $A$. versicolor isolated from poorly maintained 
air-conditioners located in operating rooms was reported by Gniadek and Macura (2011).

The presence of Aspergillus in hospital environments raises great concern, especially for its ability to produce allergens that are released into the air, which can affect the health of sensitized individuals. The increase in the concentration of Aspergillus spp. indoors will cause the exacerbation of asthma, for example (Zubairi et al., 2014). A. flavus, $A$. fumigatus, $A$. niger, $A$. oryzae and $A$. versicolor are the species that produce allergens, according to the WHO/IUIS Allergen Nomenclature Sub-committee (www.allergen.org), the allergen website approved by the World Health Organization (Table 2). Out of all, A. fumigatus is the one presenting the highest amount of allergens described, while for $A$. flavus and $A$. versicolor there is only one allergen description for each species. Allergens from $A$. flavus and $A$. niger were identified, and the allergic response to them was confirmed by allergy skin test and serum IgE test (Verman et al., 2015). In tests using serum from asthmatic patients, a $34-\mathrm{kD}$ alkaline serine protease was identified as $A$. oryzae allergen (Shen et al., 1998). Allergens of A. fumigatus Asp f 18 and Asp f 34 have been identified in serum of asthmatic patients and with allergic bronchopulmonary aspergillosis (ABPA), respectively (Shen et al., 2001; Glaser et al., 2009). A review covering various aspects of allergens produced by $A$. fumigatus can be seen in the study published by Kurup (2005).

\section{Genus Penicillium}

The genus Penicillium has species whose occurrence has been verified in a wide variety of habitats, especially with great prevalence in indoor air environments (Visagie et al., 2014). In hospital settings, its presence as a contaminant of indoor air has been constantly verified. Sepahvand et al., (2013) found
Penicillium as the most prominent genus of isolated fungi present in the microflora of indoor air in five hospitals. Similarly, a study conducted in order to evaluate the presence of fungi in indoor air of a hospital Oncology Unit also pointed this genus as the most frequent in air samples (Okten et al., 2015). In critical public and private hospitals areas, analysis of samples collected in filters and airconditioning palettes showed contamination with Penicillium sp. (Santana and Fortune 2012), which in this type of environment, due to the precarious health condition of many patients, may represent a risk to their recovery.

Penicillium mainly affects immunosuppressed individuals, being this impaired immune system a result from a primary infection with human immunodeficiency virus (HIV) or caused by some sort of treatment (Barcus et al., 2005). The first report of human infection by this fungus was observed in 1973, when Penicillium marneffei isolation from the spleen of a patient with Hodgkin's disease was described (Disalvo et al., 1973). In fact, $P$. marneffei has been the most frequent species reported in human infections (Vanittanakom et al., 2006; Yu et al., 2018), although rare infections by other species have also been reported (Geltner et al., 2013; Oshikata et al., 2013; Radulesco et al., 2018).

The importance of Penicillium as a fungus that produces allergens and its presence in indoor air environments has currently received great attention. A review published by Sharpe and collaborators (2015) highlights the relationship between the exposure to fungal allergen from some species in indoor air environment and asthma cases. For example, the severity of asthma was associated with Penicillium exposure (Pongracic et al., 2010). The official website of Allergens highlights Penicillium brevicompactum, Penicillium chrysogenum, Penicillium citrinum, 
Penicillium crustosum and Penicillium oxalicum as allergenic species. A $68 \mathrm{kDa}$ allergen, produced by $P$. chrysogenum (previously named Penicillium notatum), was characterized by molecular biology and identified as N-acetyl-glucosaminidase (Shen et al., 1995). Allergens produced by $P$. oxalicum and $P$. chrysogenum were immunologically reactive with serum from asthmatic individuals, as well as showing homology with allergen produced by $P$. citrinum and a vacuolar serine protease from A. fumigatus (Shen et al., 1999). Molecular cloning of genes encoding allergens in $P$. brevicompactum revealed the presence of an allergenic clone named Pen b 26 which was reactive with serum from sensitive individuals, the allergen being identified as a ribosomal protein (Sevinc et al., 2005). Isolation and characterization of an allergen (Pen cr 26) produced by $P$. crustosum was reported by Sevin et al., (2014). Pen cr 26 presented strong sequence homology with Pen b 26; however, the authors described the existence of antigenic differences among $\operatorname{IgE}$ epitopes, which led them to consider Pen cr 26 as a hypoallergenic variant of Pen $b$ 26. Table 3 shows the allergens recognized and approved by WHO/IUIS Allergen Nomenclature.

\section{Genus Cladosporium}

Cladosporium involves fungi with a wide worldwide distribution and which are also isolated from materials commonly found in environments such as paints, wood, textiles and other organic compounds (Andersen et al., 2000; 2011). Conidia of species of this genus are commonly isolated from the air (Pavan and Manjunath 2014; Weryszko-Chmielewska et al., 2018). Although the highest prevalence of Cladosporium is verified in atmospheric air (Zoppas et al., 2011), its isolation in indoor air environments has also been verified (Nambu et al., 2009). The occurrence of this fungus as one of the most prevalent in the air of hospital environments has been verified in the literature. By analyzing the presence of contaminating fungi in the air-conditioning devices in intensive care units and operating rooms, the authors found Cladosporium as one of the most prevalent genera (ABOUL-NASR et al., 2014). These results emphasize the contribution of air-conditioning equipment to the contamination of air in hospital units, which significantly compromises patient recovery. Although Cladosporium species are rare as human pathogens, they are involved in cutaneous infections, phaeohyphomycosis and pulmonary infections (Viheira and Pacheco 2001; Tasic and Tasic 2007; Castro et al., 2013), some of them presenting significant aggravation, which can represent an enormous risk to hospitalized patients. Additional studies have also observed the presence of Cladosporium as one of the main air pollutants in hospital environments (Lobato et al., 2009; Maldonado-Vega et al., 2014; Chaivisit et al., 2018).

The presence of Cladosporium in environments with indoor air is considerably influenced by atmospheric air. Spores of this fungus have allergens that can affect the health of sensitive individuals and have been associated with exacerbation of asthma in children (Raphoz et al., 2010). According to WHO/IUIS Allergen Nomenclature, Cladosporium cladosporioides and Cladosporium herbarum are the species whose allergens have been identified so far. Out of these species, $C$. herbarum receives greater attention due to the greater number of allergens it produces (Table 4). Many of the allergens produced by Cladosporium show cross-reactivity with allergens of other fungi, especially with species of the genus Alternaria (Achatz et al., 1995). Chou et al., (2008) reported the identification of a serine protease as the main allergen of $C$. cladosporioides. The authors also observed the reactivity of this allergen with serum of asthmatic patients, as 
well as the cross-reactivity of this allergen with Aspergillus ssp. allergens and Penicillium ssp. NADP-dependent mannitol dehydrogenase was recognized by $\operatorname{IgE}$ antibodies in $57 \%$ of $C$. herbarum-sensitive patients, having been considered the main allergen of this species (Simon-Nobbe et al., 2006). Monosensitization to Cladosporium allergens has rarely occurred, which can be attributed largely to cross-reactivity with allergens of other species.

\section{Genus Alternaria}

Alternaria is one among the most prevalent fungi in the atmospheric air, along with Aspergillus and Cladosporium. Although the highest concentrations of their spores are observed in the atmosphere, their presence in indoor air environments has also been reported (Sharma et al., 2011; Fang et al., 2013).

Alternaria alternata has been described as one of the most prevalent fungal species in indoor air environments in the United States (Woudenberg et al., 2015). In the hospital environment, the presence of Alternaria in air samples collected in a neonatal unit has been mentioned (Sakartepe et al., 2016). The occurrence of Alternaria ssp. was also described in an Intensive Care Unit and apartments of a hospital unit in the city of Francisco Beltrão (Flores and Onofre 2010). A study by Godini et al., (2015) found a high level of fungal bioaerosols in hospital air samples, with Alternaria ssp. being among the most prevalent fungi.

Despite being considered essentially a phytopathogen, species of this genus have been related to cases of infections in humans. Most of these infections are opportunistic, especially affecting individuals with impaired immune function (Moreno et al., 2012). The clinical manifestations involve mainly cutaneous and subcutaneous infections, although other types of infections may also occur (Pastor and Guarro 2008). Patients who underwent transplantation may be susceptible to Alternaria infections, including those caused by more than one species (Brás et al., 2015). Recently, A. alternata has been related to cases of cutaneous and visceral phaeohyphomycosis (Gomes et al., 2011; Raza et al., 2015).

Table.1 Limit concentrations for fungal bioaerosols in indoor air environments established in some countries. Adapted from Mandal and Brandl (2011)

\begin{tabular}{|c|c|c|}
\hline COUNTRY & $\begin{array}{c}\text { FUNGI CONCENTRATION IN } \\
\text { THE ENVIRONMENT - CFU / m3 }\end{array}$ & REFERENCES \\
\hline Brazil & 750 & (Nunes et al. 2005) \\
\hline Canada & 150 & (Bartlett et al. 2002) \\
\hline Germany & 10000 & (Ifa 2004) \\
\hline Portugal & 500 & (Handles et al. 2010) \\
\hline Russia & $2000-1000$ & (Eduard 2009) \\
\hline Switzerland & 1000 & \\
\hline United States & 1000 & (Oppliger et al. 2005) \\
\hline \multirow{2}{*}{ European Union } & $2000-$ Non-industrial environments & (Warner et al. 1994) \\
\hline
\end{tabular}


Table.2 Aspergillus allergens recognized by WHO/IUIS Allergen Nomenclature Sub-committee

\begin{tabular}{|c|c|c|c|}
\hline Fungus/Allergen & Size $(k D)$ & Biological Activity & $\begin{array}{c}\text { Sequence access } \\
\text { number }\end{array}$ \\
\hline \multicolumn{4}{|l|}{ Aspergillus flavus } \\
\hline Asp fl 13 & 34 & alkaline serine protease & $*$ \\
\hline \multicolumn{4}{|l|}{ Aspergillus fumigatus } \\
\hline Asp f 1 & 18 & Ribonuclease & M83781 \\
\hline Asp f 2 & 37 & Unknown & U56938 \\
\hline Asp f 3 & 19 & Peroxisomal protein & U58050 \\
\hline Asp f 4 & 30 & Unknown & AJ001732 \\
\hline Asp f 5 & 40 & Metalloprotease & Z30424 \\
\hline Asp f 6 & 26.5 & Mn superoxide dismutase & U53561 \\
\hline Asp f 7 & 12 & Unknown & AJ223315 \\
\hline Asp f 8 & 11 & Ribosomal protein P2 & AJ224333 \\
\hline Asp f 9 & 34 & Unknown & AJ223327 \\
\hline Asp f 10 & 34 & Aspartic protease & X85092 \\
\hline Asp f 11 & 24 & Peptidyl prolyl isomerase & AJ006689 \\
\hline Asp f 12 & 90 & Heat shock protein $\mathrm{P} 90$ & U92465 \\
\hline Asp f 13 & 34 & Serine alkaline protease & Z11580 \\
\hline Asp f 15 & 16 & Unknown & AJ002026 \\
\hline Asp f 16 & 43 & Unknown & AF062651 \\
\hline Asp f 17 & - & Unknown & AJ224865 \\
\hline Asp f 18 & 34 & Vacuolar serine protease & Y13338 \\
\hline Asp f 22 & 46 & Enolase & AF284645 \\
\hline Asp f 23 & 44 & Ribosomal protein L3 & AF464911 \\
\hline Asp f 27 & 18 & Cyclofiline / Isomerase & AJ937743 \\
\hline Asp f 28 & 13 & Thioredoxin & AJ937744 \\
\hline Asp f 29 & 13 & Thioredoxin & AJ937745 \\
\hline Asp f 34 & 20 & Cell wall protein & AM496018 \\
\hline \multicolumn{4}{|l|}{ Aspergillus niger } \\
\hline Asp n 14 & 105 & B-xylosidase & AF108944 \\
\hline Asp n 18 & 34 & Vacuolar serine protease & $*$ \\
\hline Asp n 25 & $66-100$ & 3-phytase / Hidrolase & L20567 \\
\hline \multicolumn{4}{|l|}{ Aspergillus oryzae } \\
\hline Asp o 13 & 34 & Alkaline serine protease & $\mathrm{X} 17561$ \\
\hline Asp o 21 & 53 & Taka Amilase A & M33218/ D00434 \\
\hline \multicolumn{4}{|l|}{ Aspergillus versicolor } \\
\hline Asp v 13 & 43 & $\begin{array}{c}\text { Extracellular alkaline serine } \\
\text { protease }\end{array}$ & GU827714 \\
\hline
\end{tabular}


Table.3 Penicillium allergens recognized by WHO/IUIS Allergen Nomenclature Sub-committee

\begin{tabular}{|c|c|c|c|}
\hline Fungus/Allergen & Size (kD) & Biological Activity & $\begin{array}{c}\text { Sequence } \\
\text { access } \\
\text { number }\end{array}$ \\
\hline \multicolumn{4}{|l|}{$\begin{array}{c}\text { Penicillium } \\
\text { brevicompactum }\end{array}$} \\
\hline Pen b 13 & 33 & Alkaline serine protease & $*$ \\
\hline Pen b 26 & 11 & Ribosomal acid protein $60 \mathrm{~S}$ & AY786077 \\
\hline \multicolumn{4}{|l|}{$\begin{array}{l}\text { Penicillium } \\
\text { chrysogenum }\end{array}$} \\
\hline Pen ch 13 & 34 & Alkaline serine protease & AF193420 \\
\hline Pen ch 18 & 32 & Vacuolar serine protease & AF264027 \\
\hline Pen ch 20 & 68 & $\mathrm{~N}$-acetyl-glucosaminidase & S77837 \\
\hline Pen ch 31 & & Calreticulin & AY850367 \\
\hline Pen ch 33 & 16 & unknown & EF206657.1 \\
\hline Pen ch 35 & 36.5 & Transaldolase & GQ925430 \\
\hline \multicolumn{4}{|l|}{ Penicillium citrinum } \\
\hline Pen c 3 & 18 & Peroxisomal membrane protein & AF144753 \\
\hline Pen c 13 & 33 & Alkaline serine protease & $*$ \\
\hline Pen c 19 & 70 & Heat shock protein $\mathrm{P} 70$ & U64207 \\
\hline Pen c 22 & 46 & Enolase & AF254643 \\
\hline Pen c 24 & & Elongation factor $1 \beta$ & AY363911 \\
\hline Pen c 30 & 97 & Catalase & DQ288844 \\
\hline Pen c 32 & 40 & Pectate lyase & EF159713 \\
\hline \multicolumn{4}{|l|}{ Penicillium crustosum } \\
\hline Pen cr 26 & 11 & $\begin{array}{l}\text { Acid ribosomal phosphoprotein } \\
\text { P1 60s }\end{array}$ & JN791438 \\
\hline \multicolumn{4}{|l|}{ Penicillium oxalicum } \\
\hline Pen o 18 & 34 & Vacuolar serine protease & AF243425 \\
\hline
\end{tabular}


Table.4 Cladosporium allergens recognized by WHO/IUIS allergen nomenclature subcommittee

\begin{tabular}{|c|c|c|c|}
\hline Fungus/Allergen & Size $(k D)$ & Biological Activity & $\begin{array}{l}\text { Sequence } \\
\text { access } \\
\text { number }\end{array}$ \\
\hline \multicolumn{4}{|l|}{$\begin{array}{l}\text { Cladosporium } \\
\text { cladosporioides }\end{array}$} \\
\hline Cla c 9 & 36 & Vacuolar serine protease & EF407520 \\
\hline Cla c 14 & 36.5 & Transaldolase & GQ906475 \\
\hline \multicolumn{4}{|l|}{$\begin{array}{l}\text { Cladosporium } \\
\text { herbarum }\end{array}$} \\
\hline Cla h 2 & 45 & & * \\
\hline Cla h 5 & 11 & Acid ribosomal protein $\mathrm{P} 2$ & X78223 \\
\hline Cla h 6 & 46 & Enolase & X78226 \\
\hline Cla h 7 & 22 & Protein YCP4 & X78224 \\
\hline Cla h 8 & 28 & Mannitol dehydrogenase & AY191816 \\
\hline Cla h 9 & & Vacuolar serine protease & AY787775 \\
\hline Cla h 10 & 53 & Aldehyde dehydrogenase & X78228 \\
\hline Cla h 12 & 11 & Acid ribosomal protein P1 & X85180 \\
\hline
\end{tabular}

Table.5 Alternaria allergens recognized by WHO/IUIS allergen nomenclature sub-committee

\begin{tabular}{|c|c|c|c|}
\hline Fungus/Allergen & Size (kD) & Biological Activity & $\begin{array}{c}\text { Sequence access } \\
\text { number }\end{array}$ \\
\hline Alternaria alternata & & Unknown & $\begin{array}{c}\text { AY568627 } \\
\text { U82633 U86752 }\end{array}$ \\
\hline Alt a 1 & $\begin{array}{l}16.4 \text { and } 15.3 \\
(30 \text { non red) }\end{array}$ & Heat shock protein P70 & U87807 U87808 \\
\hline Alt a 3 & & Dissulfide isomerase & X84217 \\
\hline Alt a 4 & 57 & Ribosomal protein P2 & X78222 U87806 \\
\hline Alt a 5 & 11 & Enolase & U82437 \\
\hline Alt a 6 & 45 & Protein YCP4 & X78225 \\
\hline Alt a 7 & 22 & Mannitol dehydrogenase & AY191815 \\
\hline Alt a 8 & 29 & Aldehyde dehydrogenase & X78227 \\
\hline Alt a 10 & 53 & Acid ribosomal protein P1 & X84216 \\
\hline Alt a 12 & 11 & Glutathione-s-transferase & AY514673 \\
\hline Alt a 13 & 26 & dismutase & KC923297 \\
\hline Alt a 14 & 24 (reduced) & Mn-dependent superoxide & KJ558435 (awaiting \\
& & release) \\
\hline Alt a 15 & 58 & Serine protease & \\
\hline
\end{tabular}


Table.6 Fusarium allergens recognized by WHO/IUIS allergen nomenclature sub-committee

\begin{tabular}{|c|c|c|c|}
\hline Fungus/Allergen & Size (kD) & Biological Activity & $\begin{array}{c}\text { Sequence } \\
\text { access } \\
\text { number }\end{array}$ \\
\hline Fusarium culmorum & & & \\
\hline Fus c 1 & 11 & Ribosomal protein P2 & AY077706 \\
\hline Fus c 2 & 13 & Thioredoxin-like protein & AY077707 \\
\hline \begin{tabular}{c|c|c|} 
Fuusarium \\
proliferatum
\end{tabular} & & Transaldolase & \\
\hline Fus p 4 & 37.5 & Vacuolar serine protease & KF151224 \\
\hline Fus p 9 & 36.5 & &
\end{tabular}

The major importance of Alternaria is undoubtedly related to its position as one of the main genera of allergenic fungi, with a singular prominence for the A. alternata species. Association of Alternaria sp. with asthma, hypersensitive pneumonitis and allergic rhinitis (Pastor and Guarro, 2008), as well as the involvement in cases of respiratory arrest (O'hollaren et al., 1991) has been verified in the literature. Pulimood et al., (2007) found that the exposure of individuals susceptible to Alternaria may influence the increase in symptoms related to asthma. Exposure to spores of these fungi has also been associated with increased risks of hospitalizations for asthmatic children and adolescents (Tham et al., 2016).

A. alternata is the only species of the genus that has allergens identified and approved by the WHO/IUIS Allergen Nomenclature SubCommittee (Table 5). Out of all the identified allergens, Alt a 1 is the most important, having high reactivity with sera from sensitive individuals as well as a high allergenicity.

Twaroch et al., (2012) have speculated that Alt a 1 is located in the cell wall of Alternaria spores, and in this way may contribute to the upper airway related symptoms of sensitive individuals. Recently, some published reviews have specifically addressed the allergens produced by A. alternata, as well as the role of each one in the development of respiratory allergies caused by fungi (Kustrzeba-Wójcicka et al., 2014; Gabriel et al., 2016).

\section{Genus Fusarium}

Species of the genus Fusarium are widely distributed and recognized as an important plant pathogen. Many species are mycotoxin producers, which are toxic secondary metabolites whose toxicity can affect human health (Antonissen et al., 2014). Among the many effects, exposure to these mycotoxins may affect the intestinal epithelium (Liew and Mohd-Redzwan, 2018), as well as lead to an effect on the immune system (Maresca 2013). Fusarium has been linked to a broad spectrum of infections in individuals with immune problems. In these individuals the clinical manifestations related to fusariosis involve endophthalmitis, sinusitis, pneumonia, skin problems, as well as fungemia (Nucci and Anaissie 2007). Immunosuppressed lung transplant patients have often been affected by fusariosis (Carneiro et al., 2011).

The presence of Fusarium as an indoor air contaminant has been mentioned in the literature (Hsu et al., 2012; Ziehe et al., 
2014). Likewise, contamination of the air in hospital environments by this fungus can also occur, significantly compromising patient recovery. Pantoja et al., (2012), when analyzing the fungal biodiversity in the air of hospitals in the city of Fortaleza/Brazil, verified the presence of Fusarium spp. in all hospitals and in several of the sampled environments. Other studies on the biological contamination of air in hospitals have also shown the presence of this fungus (Awosika et al., 2012; Emuren and Ordinioha 2016). The WHO/IUIS Allergen Nomenclature SubCommittee identified and approved four Fusarium allergens (Table 6). The association of asthma with allergens of this fungus in sensitive individuals has been reported in the literature (Khosravi et al., 2012). Hoff et al., (2003) characterized and identified an allergen produced by Fusarium culmorum, which was reactive in $44 \%$ of sera from susceptible individuals. A transaldolase was identified as an allergen of Fusarium proliferatum, and this allergen was further verified to have cross-reactivity with the allergen (transaldolase) produced by Cladosporium as well as with human transaldolases (Chou et al., 2014).

In conclusion, artificially air-conditioned environments represent one of many habitats where development and establishment of many fungal species can occur. Humidity, temperature, as well as nutrient availability and neglected maintenance of refrigeration systems are fundamental requirements for mold growth in indoor air-conditioned environments. In hospital settings, the presence of anemophilous fungi circulating throughout the hospital poses a great risk to all those present and this should be considered. Health professionals, visitors and patients, especially those patients who are immunologically compromised, can be significantly affected when exposed to fungal contaminants in the air. Many of the anemophilous fungi commonly found in hospital air quality analyses are pathogenic and represent an even greater challenge because of the ability to produce allergens. Since many of the allergens produced are related to various respiratory illnesses in children and adults, maintaining a hospital environment free from contamination and with good air quality becomes a major challenge. In this context, a better understanding of all risks associated with exposure to fungi in indoor environments may lead to measures that contribute to minimizing the implications for human health, especially in maintaining a safer location.

\section{References}

Abbasi, F., and Samaei, M. R. (2018). The effect of temperature on airborne filamentous fungi in the indoor and outdoor space of a hospital. Environmental Science and Pollution Research, 1-9.

Aboul-Nasr, M. B., Zohri, Abdel-Naser, M., and Amer, E. M. (2014). Indoor Surveillance of Airborne Fungi Contaminating Intensive Care Units and Operation Rooms in Assiut University Hospitals, Egypt. Journal of health science, 2(1). doi:10.17265/23287136/2014.01.003

Achatz, G., Oberkofler, H., Lechenauer, E., Simon, B., Unger, A., Kandler, D., et al., (1995). Molecular cloning of major and minor allergens of Alternaria alternata and Cladosporium herbarum. Molecular immunology, 32(3), 213-227.

Ahearn, D. G., Price, D. L., Simmons, R., Noble-Wang, J., and Crow, S. A., Jr. (2004). Indoor moulds and their associations with air distribution systems. Advances in applied microbiology, 55, 113-138.

American Conference of Governmental Industrial Hygienists (ACGIH). (2012). Threshold limit values (TLVs) for 
chemical substances and physical agents and biological exposure indices (BEIs). Cincinnati, USA.

Andersen, B., Frisvad, J. C., Søndergaard, I., Rasmussen, I. S., and Larsen, L. S. (2011). Associations between fungal species and water-damaged building materials. Applied and environmental microbiology, 77(12), 4180-4188.

Antonissen, G., Martel, A., Pasmans, F., Ducatelle, R., Verbrugghe, E., Vandenbroucke, V., et al., (2014). The impact of Fusarium mycotoxins on human and animal host susceptibility to infectious diseases. Toxins, 6(2), 430 452.

Aquino, S., de Lima, J. E. A., do Nascimento, A. P. B., and Reis, F. C. (2018). Analysis of fungal contamination in vehicle air filters and their impact as a bioaccumulator on indoor air quality. Air quality, atmosphere, and health. doi:10.1007/s11869-018-0614-0

Arnow, P. M., Andersen, R. L., Mainous, P. D., and Smith, E. J. (1978). Pulmonary aspergillosis during hospital renovation. The American review of respiratory disease, 118(1), 49-53.

Arnow, P. M., Sadigh, M., Costas, C., Weil, D., and Chudy, R. (1991). Endemic and epidemic aspergillosis associated with inhospital replication of Aspergillus organisms. The Journal of infectious diseases, 164(5), 998-1002.

Asif, A., Zeeshan, M., Hashmi, I., Zahid, U., and Bhatti, M. F. (2018). Microbial quality assessment of indoor air in a large hospital building during winter and spring seasons. Building and environment, 135, $68-73$.

Awad, A. H., Saeed, Y., Hassan, Y., Fawzy, Y., and Osman, M. (2018). Air microbial quality in certain public buildings, Egypt: A comparative study. Atmospheric Pollution Research, 9(4), 617-626.

Awosika, S. A., Olajubu, F. A., and Amusa, N. A. (2012). Microbiological assessment of indoor air of a teaching hospital in Nigeria. Asian Pacific journal of tropical biomedicine, 2(6), 465-468.

Barcus, A. L., Burdette, S. D., and Herchline, T.

E. (2005). Intestinal invasion and disseminated disease associated with Penicillium chrysogenum. Annals of clinical microbiology and antimicrobials, 4, 21.

Barrs, V. R., van Doorn, T. M., Houbraken, J., Kidd, S. E., Martin, P., Pinheiro, M. D., et al., (2013). Aspergillus felis sp. nov., an emerging agent of invasive aspergillosis in humans, cats, and dogs. PloS one, 8(6), e64871.

Bartlett, K. H., Lee, K. S., Stephens, G., Black, W., Brauer, M., and Copes, R. (2002). Evaluating indoor air quality: test standards for bioaerosols. Doi: http://dx.doi.org/10.14288/1.0048213

Batterman, S. A., and Burge, H. (1995). HVAC Systems as Emission Sources Affecting Indoor Air Quality: A Critical Review: Project Summary.

Baughman, A., and Arens, E. A. (1996). Indoor Humidity and Human Health--Part I: Literature Review of Health Effects of Humidity-Influenced Indoor Pollutants. ASHRAE Transactions, 102 Part 1, 192211.

Beggs, C. B. (2003). The Airborne Transmission of Infection in Hospital Buildings: Fact or Fiction? Indoor and Built Environment, 12(1-2), 9-18.

Bensch, K., Braun, U., Groenewald, J. Z., and Crous, P. W. (2012). The genus Cladosporium. Studies in mycology, 72, $1-401$

Bessonneau, V., Mosqueron, L., Berrubé, A., Mukensturm, G., Buffet-Bataillon, S., Gangneux, J.-P., and Thomas, O. (2013). VOC contamination in hospital, from stationary sampling of a large panel of compounds, in view of healthcare workers and patients exposure assessment. PloS one, 8(2), e55535.

Bielawska-Drózd, A., Cieślik, P., Bohacz, J., Korniłłowicz-Kowalska, T., Żakowska, D., Bartoszcze, M., et al., (2018). Microbiological analysis of bioaerosols collected from Hospital Emergency 
Departments and ambulances. Annals of agricultural and environmental medicine: AAEM, 25(2), 274-279.

Brás, S., Sabino, R., Laureano, A., Simões, H., Fernandes, C., Marques-Pinto, G., et al., (2015). Cutaneous infection by different Alternaria species in a liver transplant recipient. Medical mycology case reports, $8,1-4$.

Caillaud, D., Leynaert, B., Keirsbulck, M., Nadif, R., and mould ANSES working group. (2018). Indoor mould exposure, asthma and rhinitis: findings from systematic reviews and recent longitudinal studies. European respiratory review: an official journal of the European Respiratory Society, 27(148). doi:10.1183/16000617.0137-2017

Carneiro, H. A., Coleman, J. J., Restrepo, A., and Mylonakis, E. (2011). Fusarium infection in lung transplant patients: report of 6 cases and review of the literature. Medicine, 90(1), 69-80.

Castro, A. S., Oliveira, A., and Lopes, V. (2013). Pulmonary phaeohyphomycosis: a challenge to the clinician. European respiratory review: an official journal of the European Respiratory Society, 22(128), 187-188.

Chaivisit, P., Fontana, A., Galindo, S., Strub, C., Choosong, T., Kantachote, D., and Suksaroj, T. T. (2018). Airborne Bacteria and Fungi Distribution Characteristics in Natural Ventilation System of a University Hospital in Thailand. EnvironmentAsia, 11(2), 53-66.

Chou, H., Tam, M. F., Lee, L.-H., Chiang, C.H., Tai, H.-Y., Panzani, R. C., and Shen, H.-D. (2008). Vacuolar serine protease is a major allergen of Cladosporium cladosporioides. International archives of allergy and immunology, 146(4), 277286.

Chou, H., Wu, K.-G., Yeh, C.-C., Tai, H.-Y., Tam, M. F., Chen, Y.-S., and Shen, H.-D. (2014). The transaldolase, a novel allergen of Fusarium proliferatum, demonstrates IgE cross-reactivity with its human analogue. PloS one, 9(7), e103488.

Coombs, K., Taft, D., Ward, D. V., Green, B. J., Chew, G. L., Shamsaei, B., et al., (2018). Variability of indoor fungal microbiome of green and non-green low-income homes in Cincinnati, Ohio. The Science of the total environment, 610-611, 212218.

Crawford, J. A., Rosenbaum, P. F., Anagnost, S. E., Hunt, A., and Abraham, J. L. (2015). Indicators of airborne fungal concentrations in urban homes: understanding the conditions that affect indoor fungal exposures. The Science of the total environment, 517, 113-124.

DiSalvo, A. F., Fickling, A. M., and Ajello, L. (1973). Infection caused by Penicillium marneffei: description of first natural infection in man. American journal of clinical pathology, 60(2), 259-263.

Dubey, S., Lanjewar, S., Sahu, M., Pandey, K., and Kutti, U. (2011). The Monitoring of Filamentous Fungi in the Indoor Air Quality, and Health. Journal of Phytology, 3(4).

Dürmaz, G., Kiremitçi, A., Akgün, Y., Oz, Y., Kaşifoğlu, N., Aybey, A., and Kiraz, N. (2005). The relationship between airborne colonization and nosocomial infections in intensive care units. Mikrobiyoloji bulteni, 39(4), 465-471.

Eduard, W. (2009). Fungal spores: a critical review of the toxicological and epidemiological evidence as a basis for occupational exposure limit setting. Critical reviews in toxicology, 39(10), 799-864.

Eickhoff, T. C. (1994). Airborne nosocomial infection: a contemporary perspective. Infection control and hospital epidemiology: the official journal of the Society of Hospital Epidemiologists of America, 15(10), 663-672.

Emuren, K., and Ordinioha, B. (2016). Microbiological assessment of indoor air quality at different sites of a tertiary hospital in South-South Nigeria. Port Harcourt Medical Journal, 10(2), 79-84.

Environmental Surveillance of Filamentous 
Fungi in Hospital Air Sampling. Journal of Microbiology, Immunology and Biotechnology, 2, 22-24.

Fang Z. G., Ouyang Z. Y., Liu P., Sun L., and Wang X.-Y. (2013). [Airborne fungal community composition in indoor environments in Beijing]. Huan Jing Ke Xue], 34(5), 2031-2037.

Flores, L. H., and Onofre, S. B. (2010). Determinação da presença de fungos anemófilos e leveduras em unidade de saúde da cidade de Francisco Beltrão-PR. SaBios-Revista de Saúde e Biologia, 5(2), 22-26.

Gabriel, M. F., Postigo, I., Tomaz, C. T., and Martínez, J. (2016). Alternaria alternata allergens: Markers of exposure, phylogeny and risk of fungi-induced respiratory allergy. Environment international, 89-90, 71-80.

Gangneux, J.-P., Robert-Gangneux, F., Gicquel, G., Tanquerel, J.-J., Chevrier, S., Poisson, M., et al., (2006). Bacterial and fungal counts in hospital air: comparative yields for 4 sieve impact or air samplers with 2 culture media. Infection control and hospital epidemiology: the official journal of the Society of Hospital Epidemiologists of America, 27(12), 1405-1408.

Geltner, C., Lass-Flörl, C., Bonatti, H., Müller, L., and Stelzmüller, I. (2013). Invasive pulmonary mycosis due to Penicillium chrysogenum: a new invasive pathogen. Transplantation, 95(4), e21-3.

Ghaffarianhoseini, A., AlWaer, H., Omrany, H., Ghaffarianhoseini, A., Alalouch, C., Clements-Croome, D., and Tookey, J. (2018). Sick building syndrome: are we doing enough? Architectural Science Review, 61(3), 99-121.

Glaser, A. G., Kirsch, A. I., Zeller, S., Menz, G., Rhyner, C., and Crameri, R. (2009). Molecular and immunological characterization of Asp f 34, a novel major cell wall allergen of Aspergillus fumigatus. Allergy, 64(8), 1144-1151.

Gniadek, A., and Macura, A. B. (2011). Airconditioning vs. presence of pathogenic fungi in hospital operating theatre environment. Wiadomosci parazytologiczne, 57(2), 103-106.

Godini, H., Azimi, F., Kamarehie, B., Mohammadin, P., Mansoury, N., Norozian, H., and Ghobadian, H. (2015). Bio-aerosols concentrations in different wards of Khorramabad Hospital, Iran, 2013. International Journal of Environmental Health Engineering, 4(2), 23.

Gomes, J., Vilarinho, C., Duarte, M. da L., and Brito, C. (2011). Cutaneous Phaeohyphomycosis Caused by Alternaria alternata Unresponsive to Itraconazole Treatment. Case reports in dermatological medicine, 2011, 385803.

Górny, R. L., Reponen, T., Willeke, K., Schmechel, D., Robine, E., Boissier, M., and Grinshpun, S. A. (2002). Fungal Fragments as Indoor Air Biocontaminants. Applied and environmental microbiology, 68(7), 3522-3531.

Hachem, R., Gomes, M. Z. R., El Helou, G., El Zakhem, A., Kassis, C., Ramos, E., et al., (2014). Invasive aspergillosis caused by Aspergillus terreus: an emerging opportunistic infection with poor outcome independent of azole therapy. The Journal of antimicrobial chemotherapy, 69(11), 3148-3155.

Hambraeus, A. (1988). Aerobiology in the operating room--a review. The Journal of hospital infection, 11 Suppl A, 68-76.

Hamilton, E. D. (1959). Studies on the air spora. Acta allergologica, 13(2), 143-173.

Hedayati, M. T., Pasqualotto, A. C., Warn, P. A., Bowyer, P., and Denning, D. W. (2007). Aspergillus flavus: human pathogen, allergen and mycotoxin producer. Microbiology, 153(6), 16771692.

Hirst, J. M. (1952). An automatic volumetric spore trap. The Annals of applied biology, 39(2), 257-265.

Hoff, M., Ballmer-Weber, B. K., Niggemann, B., Cistero-Bahima, A., San MiguelMoncín, M., Conti, A., et al., (2003). 
Molecular cloning and immunological characterisation of potential allergens from the mould Fusarium culmorum. Molecular immunology, 39(15), 965-975.

Holý, O., Matoušková, I., Kubátová, A., Hamal, P., Svobodová, L., Jurásková, E., and Raida, L. (2015). Monitoring of Microscopic Filamentous Fungi in Indoor Air of Transplant Unit. Central European journal of public health, 23(4), 331-334.

Hong, W. P., Shin, J. H., Shin, D. H., Sul, Y., Lee, C. J., Suh, S. P., and Ryang, D. W. (1999). Filamentous Fungi Isolated from Hospital Air and from Clinical Specimens. Korean Journal of Nosocomial Infection Control, 4(1), 1725.

Hsu, Y.-C., Kung, P.-Y., Wu, T.-N., and Shen, Y.-H. (2012). Characterization of indoorair bioaerosols in Southern Taiwan. Aerosol and Air Quality Research, 12(4), 651-661.

Institut für Arbeitsschutz der Deutschen Gesetzlichen Unfallversicherung (IFA). (2004). Verfahren zur Bestimmung der Bakterienkonzentration in der Luft am Arbeitsplatz. Berlin, Germany, Erich Schmidt Verlag.

Johansson, P., Samuelson, I., Ekstrand-Tobin, A., Mjörnell, K., Sandberg, P. I., and Sikander, E. (2005).

"Microbiological growth on building materials - critical moisture levels. State of the art," SP Report 11, SP Swedish National Testing and Research Institute.

Joshi, S. M. (2008). The sick building syndrome. Indian journal of occupational and environmental medicine, 12(2), 61.

Kemp, P. C., Neumeister-Kemp, H. G., Lysek, G., and Murray, F. (2001). Survival and growth of micro-organisms on air filtration media during initial loading. Atmospheric environment, 35(28), 47394749.

Khosravi, A., Fatahinia, M., Shokri, H., and Yadegari, M. (2012). Allergens from Fusarium solani Identified by immunoblotting in asthma patients in Iran. Archives of Industrial Hygiene and
Toxicology, 63(1), 1-6.

Kim, K.-H., Kabir, E., and Jahan, S. A. (2018). Airborne bioaerosols and their impact on human health. Journal of environmental sciences, 67, 23-35.

Koca, O., Altoparlak, U., Ayyildiz, A., and Kaynar, H. (2012). Persistence of nosocomial pathogens on various fabrics. The Eurasian journal of medicine, 44(1), 28-31.

Kousha, M., Tadi, R., and Soubani, A. O. (2011). Pulmonary aspergillosis: a clinical review. European respiratory review: an official journal of the European Respiratory Society, 20(121), 156-174.

Kowalski, W. (2012). Hospital Airborne Infection Control. CRC Press - Taylor and Francis Group.

Kurup, V. P. (2005). Aspergillus antigens: which are important? Medical mycology: official publication of the International Society for Human and Animal Mycology, 43 Suppl 1, S189-96.

Kushawaha, D. K. S., Farooq, U., Begum, R., Tak, V., Yadav, L., Yadav, S. K., and Yadav, J. (2015). Environmental Surveillance of Filamentous Fungi in Hospital Air Sampling. Journal of Microbiology, Immunology and Biotechnology, 2, 22-24.

Kustrzeba-Wójcicka, I., Siwak, E., Terlecki, G., Wolańczyk-Mędrala, A., and Mędrala, W. (2014). Alternaria alternata and its allergens: a comprehensive review. Clinical reviews in allergy and immunology, 47(3), 354-365.

Kwon-Chung, K. J., and Sugui, J. A. (2013). Aspergillus fumigatus--what makes the species a ubiquitous human fungal pathogen? PLoS pathogens, 9(12), e1003743.

Lee, T., Grinshpun, S. A., Martuzevicius, D., Adhikari, A., Crawford, C. M., and Reponen, T. (2006). Culturability and concentration of indoor and outdoor airborne fungi in six single-family homes. Atmospheric environment, 40(16), 29022910. 
Lehtonen, M., Reponen, T., and Nevalainen, A. (1993). Everyday activities and variation of fungal spore concentrations in indoor air. International Biodeterioration and Biodegradation, 31(1), 25-39.

Lemaire, B., Normand, A. C., Forel, J. M., Cassir, N., Piarroux, R., and Ranque, S. (2018). Hospitalized patient as source of Aspergillus fumigatus, 2015. Emerging Infectious Diseases, 24(8), 1524-1527.

Li, A., Liu, Z., Liu, Y., Xu, X., and Pu, Y. (2012). Experimental study on microorganism ecological distribution and contamination mechanism in supply air ducts. Energy and Buildings, 47, 497505.

Li, A., Liu, Z., Zhu, X., Liu, Y., and Wang, Q. (2010). The effect of air-conditioning parameters and deposition dust on microbial growth in supply air ducts. Energy and Buildings, 42(4), 449-454.

Li, Y., Leung, G. M., Tang, J. W., Yang, X., Chao, C. Y. H., Lin, J. Z., et al., (2007). Role of ventilation in airborne transmission of infectious agents in the built environment - a multidisciplinary systematic review. Indoor air, 17(1), 2 18.

Lidwell, O. M., and Noble, W. C. (1975). Fungi and clostridia in hospital air: the effect of air-conditioning. The Journal of applied bacteriology, 39(3), 251-261.

Liew, W.-P.-P., and Mohd-Redzwan, S. (2018). Mycotoxin: Its Impact on Gut Health and Microbiota. Frontiers in cellular and infection microbiology, 8(60), 1-17.

Lobato, R. C., Vargas, V. D. S., and Silveira, É. D. S. (2009). Sazonality and prevalence of airborne fungi in the hospital environment on the south of Rio Grande do Sul, Brazil. Revista da Faculdade de Ciências Médicas de Sorocaba, 11(2), 2128.

Luengas, A., Barona, A., Hort, C., Gallastegui, G., Platel, V., and Elias, A. (2015). A review of indoor air treatment technologies. Reviews in Environmental Science and Bio/Technology, 14(3), 499522.
Maddox, R. L. (1870). On an Apparatus for collecting Atmospheric Particles. The Monthly Microscopical Journal, 3(6), 286-290.

Maldonado-Vega, M., Peña-Cabriales, J. J., De Los Santos Villalobos, S., CastellanosArévalo, A. P., Camarena-Pozos, D., and Arévalo-Rivas, B. (2014). Bioaerosoles y evaluación de la calidad del aire en dos centros hospitalarios ubicados en León, Guanaguato, México. Revista internacional de contaminación ambiental, 30(4), 351-363.

Mandal, J., and Brandl, H. Bioaerosols in Indoor Environment - A Review with Special Reference to Residential and Occupational Locations. (2011). The Open Environmental and Biological Monitoring Journal, 41(1), 83-96.

Maresca, M. (2013). From the gut to the brain: journey and pathophysiological effects of the food-associated trichothecene mycotoxin deoxynivalenol. Toxins, 5(4), 784-820.

Martins-Diniz, J. N., da Silva, R. A. M., Miranda, E. T., and Mendes-Giannini, M. J. S. (2005). Monitoring of airborne fungus and yeast species in a hospital unit. Revista de saude publica, 39(3), 398-405.

Miller, J. D. (1992). Fungi as contaminants in indoor air. Atmospheric Environment, 26(12).

Moreno, M. Á. P., Alonso, I. G., de Santos, R., M., and Lacarra, T. G., (2012). Importancia del género Alternaria como productor de micotoxinas y agente causal de enfermedades humanas. Nutrición Hospitalaria, 27(6), 1772-1781.

Moreno-González, G., de Mesones, A. R., TaziMezalek, R., Marron-Moya, M. T., Rosell, A., and Mañez, R. (2016). Invasive Pulmonary Aspergillosis with Disseminated Infection in Immunocompetent Patient. Canadian respiratory journal: journal of the Canadian Thoracic Society, 2016, 1-5.

Möritz, M., Peters, H., Nipko, B., and Rüden, H. (2001). Capability of air filters to 
retain airborne bacteria and molds in heating, ventilating and air-conditioning (HVAC) systems. International journal of hygiene and environmental health, 203(56), 401-409.

Morrow, M. B., Lowe, E. P., and Prince, H. E. (1941). Mold fungi in the etiology of respiratory allergic diseases. Journal of allergy, 13(3), 215-226.

Nambu, M., Kouno, H., Aihara-Tanaka, M., Shirai, H., and Takatori, K. (2009). Detection of Fungi in Indoor Environments and Fungus-Specific IgE Sensitization in Allergic Children. The World Allergy Organization journal, 2(9), 208-212.

Naruka, K.; Gaur, J., Charaya, R. (2014). Bioaerosols in healthcare settings: a brief review. International Journal of Geology Earth and Environmental Sciences, 4(3), 2277-2081.

Nazaroff, W. W. (2013). Four principles for achieving good indoor air quality. Indoor air, 23(5), 353-356.

Nevalainen, A., Täubel, M., and Hyvärinen, A. (2015). Indoor fungi: companions and contaminants. Indoor air, 25(2), 125-156.

Nielsen, K. F., Holm, G., Uttrup, L. P., and Nielsen, P. A. (2004). Mould growth on building materials under low water activities. Influence of humidity and temperature on fungal growth and secondary metabolism. International biodeterioration and biodegradation, 54(4), 325-336.

Noble, W. C., and Clayton, Y. M. (1963). Fungi in the Air of Hospital Wards. Journal of general microbiology, 32, 397-402.

Nucci, M., and Anaissie, E. (2007). Fusarium infections in immunocompromised patients. linical microbiology reviews, 20(4), 695-704.

Nunes, Z. G., Martins, A. S., Altoe, A. L. F., Nishikawa, M. M., Leite, M. O., Aguiar, P. F., and Fracalanzza, S. E. L. (2005). Indoor air microbiological evaluation of offices, hospitals, industries, and shopping centers. Memorias do Instituto Oswaldo Cruz, 100(4), 351-357.
O’Hollaren, M. T., Yunginger, J. W., Offord, K. P., Somers, M. J., O'Connell, E. J., Ballard, D. J., and Sachs, M. I. (1991). Exposure to an Aeroallergen as a Possible Precipitating Factor in Respiratory Arrest in Young Patients with Asthma. The New England journal of medicine, 324(6), 359-363.

Occupational Safety and Health Administration (OSHA). (2008). Indoor air quality investigation. OSHA Technical Manual (OTM), Sect. II, chapter 2.

Okten, S., and Asan, A. (2012). Airborne fungi and bacteria in indoor and outdoor environment of the Pediatric Unit of Edirne Government Hospital. Environmental monitoring and assessment, 184(3), 1739-1751.

Ökten, S., Şen, B., Asan, A., and Bahadir, N. (2015). Airborne microfungi in Oncology Service of Medical School Hospital of Trakya University. Indoor and Built Environment, 24(6), 771-776.

Oppliger, A., Rusca, S., Charrière, N., Vu Duc, T., and Droz, P.-O. (2005). Assessment of bioaerosols and inhalable dust exposure in Swiss sawmills. The Annals of occupational hygiene, 49(5), 385-391.

Oshikata, C., Tsurikisawa, N., Saito, A., Watanabe, M., Kamata, Y., Tanaka, M. et al., (2013). Fatal pneumonia caused by Penicillium digitatum: a case report. BMC pulmonary medicine, 13, 16.

Pantoja, L. D. M., Couto, M. S., Junior, N. P. L., de Sousa, B. L., Mourão, C. I., and Paixão, G. C. (2012). Fungal biodiversity of air in hospitals in the city of Fortaleza, Ceará, Brazil. Revista Brasileira em Promoção da Saúde, 25(2), 192-196.

Pasanen, A.-L., Kasanen, J.-P., Rautiala, S., Ikäheimo, M., Rantamäki, J., Kääriäinen, H., and Kalliokoski, P. (2000). Fungal growth and survival in building materials under fluctuating moisture and temperature conditions. International biodeterioration and biodegradation, 46(2), 117-127.

Pastor, F. J., and Guarro, J. (2008). Alternaria infections: laboratory diagnosis and 
relevant clinical features. Clinical microbiology and infection: the official publication of the European Society of Clinical Microbiology and Infectious Diseases, 14(8), 734-746.

Paulussen, C., Hallsworth, J. E., Álvarez-Pérez, S., Nierman, W. C., Hamill, P. G., Blain, D., et al., (2016). Ecology of aspergillosis: insights into the pathogenic potency of Aspergillus fumigatus and some other Aspergillus species. Microbial biotechnology, 10(2), 296-322.

Pavan, R., and Manjunath, K. (2014). Qualitative Analysis of Indoor and Outdoor Airborne Fungi in Cowshed. Journal of mycology and plant pathology, 2014, 1-8.

Pegas, P. N., Evtyugina, M. G., Alves, C. A., Nunes, T., Cerqueira, M., Franchi, M., et al., (2010). Outdoor/indoor air quality in primary schools in Lisbon: a preliminary study. Química Nova, 33(5), 1145-1149.

Peláez, T., Muñoz, P., Guinea, J., Valerio, M., Giannella, M., Klaassen, C. H. W., and Bouza, E. (2012). Outbreak of invasive aspergillosis after major heart surgery caused by spores in the air of the intensive care unit. Clinical infectious diseases: an official publication of the Infectious Diseases Society of America, 54(3), e24-31.

Pitkäranta, M., Meklin, T., Hyvärinen, A., Paulin, L., Auvinen, P., Nevalainen, A., and Rintala, H. (2008). Analysis of fungal flora in indoor dust by ribosomal DNA sequence analysis, quantitative PCR, and culture. Applied and environmental microbiology, 74(1), 233-244.

Pongracic, J. A., O'Connor, G. T., Muilenberg, M. L., Vaughn, B., Gold, D. R., Kattan, M., et al., (2010). Differential effects of outdoor versus indoor fungal spores on asthma morbidity in inner-city children. The Journal of allergy and clinical immunology, 125(3), 593-599.

Pulimood, T. B., Corden, J. M., Bryden, C., Sharples, L., and Nasser, S. M. (2007). Epidemic asthma and the role of the fungal mold Alternaria alternata. The
Journal of allergy and clinical immunology, 120(3), 610-617.

Quadros, M. E., Lisboa, H. D. M., Oliveira, V. L. D., and Schirmer, W. N. (2009). Indoor air quality in hospitals: a case study and a critical review of current standards. Engenharia Sanitaria e Ambiental, 14(3), 431-438.

Qudiesat, K., Abu-Elteen, K., Elkarmi, A., Hamad, M., and Abussaud, M. (2009). Assessment of airborne pathogens in healthcare settings. African Journal of Microbiology Research, 3(2), 66-76.

Radulesco, T., Varoquaux, A., Ranque, S., Dessi, P., Michel, J., and Cassagne, C. (2018). A Case of Fungus Ball-Type Maxillary Sinusitis Due to Penicillium roqueforti. Mycopathologia, 183(2), 439443.

Raphoz, M., Goldberg, M. S., Garneau, M., Héguy, L., Valois, M.-F., and Guay, F. (2010). Associations between atmospheric concentrations of spores and emergency department visits for asthma among children living in Montreal. Archives of environmental and occupational health, 65(4), 201-210.

Raza, H., Ortiz, R. U., Anwar, K., and Muhammad, K. (2015). Visceral phaeohyphomycosis caused by Alternaria alternata offering a diagnostic as well as a therapeutic challenge. Saudi journal of kidney diseases and transplantation: an official publication of the Saudi Center for Organ Transplantation, Saudi Arabia, 26(2), 339-343.

Reponen, T., Lehtonen, M., Raunemaa, T., and Nevalainen, A. (1992). Effect of indoor sources on fungal spore concentrations and size distributions. Journal of aerosol science, 23, 663-666.

Richards, M. (1954). Atmospheric mold spores in and out of doors. The Journal of allergy, 25(5), 429-439.

Rowan, N. J., Johnstone, C. M., McLean, R. C., Anderson, J. G., and Clarke, J. A. (1999). Prediction of toxigenic fungal growth in buildings by using a novel modelling system. Applied and environmental 
microbiology, 65(11), 4814-4821.

Sakartepe, E., Uzan, A. H., and Gunyar, O. A. (2016). Airborne mycobiota determined in the neonatal unit of the ege university hospital. Fresenius Environmental Bulletin, 25(8), 2833-2841.

Santana, W. O. De., and Fortuna, J. L. (2012). Microbiota de aparelhos de ar condicionado das áreas críticas de hospitais públicos e particulares e sua relação com as infecções hospitalares. Revista Biociências, 18(1), 56-64.

Schirmer, W. N., Pian, L. B., Szymanski, M. S. E., and Gauer, M. A. (2011). [Air pollution in internal environments and sick building syndrome]. Ciencia and saude coletiva, 16(8), 3583-3590.

Scott, R. D. (2009). the direct medical coasts of healthcare-associated infections in U.S. hospitals and the benefits of prevention. Centers for Disease Control, Atlanta, GA.

Sepahvand, A., Shams-Ghahfarokhi, M., Allameh, A., and Razzaghi-Abyaneh, M. (2013). Diversity and distribution patterns of airborne microfungi in indoor and outdoor hospital environments in Khorramabad, Southwest Iran. Jundishapur Journal of Microbiology, 6(2). doi:10.5812/jjm.5074

Sevinc, M. S., Kumar, V., Abebe, M., Casley, W. L., and Vijay, H. M. (2005). Isolation and characterization of a cDNA clone encoding one IgE-binding fragment of Penicillium brevicompactum. International archives of allergy and immunology, 138(1), 12-20.

Sevinc, M. S., Kumar, V., Abebe, M., Lemieux, M., and Vijay, H. M. (2014). Isolation, expression and characterization of a minor allergen from Penicillium crustosum. Medical mycology: official publication of the International Society for Human and Animal Mycology, 52(1), 81-89.

Sharma, R., Deval, R., Priyadarshi, V., Gaur, S. N., Singh, V. P., and Singh, A. B. (2011). Indoor fungal concentration in the homes of allergic/asthmatic children in Delhi, India. Allergy and rhinology, 2(1), 21-32.
Sharpe, R. A., Bearman, N., Thornton, C. R., Husk, K., and Osborne, N. J. (2015). Indoor fungal diversity and asthma: a meta-analysis and systematic review of risk factors. The Journal of allergy and clinical immunology, 135(1), 110-122.

Shen, H. D., Liaw, S. F., Lin, W. L., Ro, L. H., Yang, H. L., and Han, S. H. (1995). Molecular cloning of cDNA coding for the $68 \mathrm{kDa}$ allergen of Penicillium notatum using MoAbs. Clinical and experimental allergy: journal of the British Society for Allergy and Clinical Immunology, 25(4), 350-356.

Shen, H. D., Lin, W. L., Tam, M. F., Chou, H., Wang, C. W., Tsai, J. J., et al., (2001). Identification of vacuolar serine proteinase as a major allergen of Aspergillus fumigatus by immunoblotting and N-terminal amino acid sequence analysis. Clinical and experimental allergy: journal of the British Society for Allergy and Clinical Immunology, 31(2), 295-302.

Shen, H. D., Lin, W. L., Tam, M. F., Wang, S. R., Tzean, S. S., Huang, M. H., and Han, S. H. (1999). Characterization of allergens from Penicillium oxalicum and P. notatum by immunoblotting and Nterminal amino acid sequence analysis. Clinical and experimental allergy: journal of the British Society for Allergy and Clinical Immunology, 29(5), 642-651.

Shen, H.-D., Lin, W.-L., Tam, M. F., Wang, S.R., Tsai, J.-J., Chou, H., and Han, S.-H. (1998). Alkaline serine proteinase: a major allergen of Aspergillus oryzae and its cross-reactivity with Penicillium citrinum. International archives of allergy and immunology, 116(1), 29-35.

Simmons, R. B., Price, D. L., Noble, J. A., Crow, S. A., and Ahearn, D. G. (1997). Fungal colonization of air filters from hospitals. American Industrial Hygiene Association journal, 58(12), 900-904.

Simon-Nobbe, B., Denk, U., Schneider, P. B., Radauer, C., Teige, M., Crameri, R., et al., (2006). NADP-dependent Mannitol Dehydrogenase, a Major Allergen of 
Cladosporium herbarum. The Journal of biological chemistry, 281(24), 1635416360.

Singh, A., Singh, N., and Chinna, D. (2018). Invasive fungal infections in respiratory intensive care unit: epidemiology and risk factors. Paripex - Indian Journal of Research, 7(2), 1-4.

Sowiak, M., Kozajda, A., Jeżak, K., and Szadkowska-Stańczyk, I. (2018). Does the air condition system in busses spread allergic fungi into driver space? Environmental science and pollution research international, 25(5), 5013-5023.

Sterling, T. D., Collett, C., and Rumel, D. (1991). A epidemiologia dos "edifícios doentes." Revista de Saúde Pública, 25(1), 56-63.

Tang, W., Kuehn, T. H., and Simcik, M. F. (2015). Effects of Temperature, Humidity and Air Flow on Fungal Growth Rate on Loaded Ventilation Filters. Journal of occupational and environmental hygiene, 12(8), 525-537.

Tasic, S., and Tasic, N. M. (2007). Cladosporium ssp. - Cause of Opportunistic Mycoses. Acta Fac Med Naiss, 24(1), 15-19.

Tham, R., Vicendese, D., Dharmage, S. C., Hyndman, R. J., Newbigin, E., Lewis, E., et al., (2016). Associations between outdoor fungal spores and childhood and adolescent asthma hospitalizations. The Journal of allergy and clinical immunology, 139(4), 1140-1147.e4.

Twaroch, T. E., Arcalís, E., Sterflinger, K., Stöger, E., Swoboda, I., and Valenta, R. (2012). Predominant localization of the major Alternaria allergen Alt a 1 in the cell wall of airborne spores. The Journal of allergy and clinical immunology, 129(4), 1148-1149.

Vanittanakom, N., Cooper, C. R., Jr, Fisher, M. C., and Sirisanthana, T. (2006). Penicillium marneffei infection and recent advances in the epidemiology and molecular biology aspects. Clinical microbiology reviews, 19(1), 95-110.

Veraldi, S., Grancini, A., Venegoni, L., Merlo,
V., Guanziroli, E., Menicanit, C., et al., (2016). Mycetoma Caused by Aspergillus nidulans. Acta dermato-venereologica, 96(1), 118-119.

Vermani, M.; Vijayan, V. K.; Agarwal, M. K. Identification of Aspergillus (A. flavus and $A$. niger) allergens and heterogeneity of allergic patients' IgE response. (2015). Iranian Journal of Allergy, Asthma and Immunology, 14(4), 361-369.

Vermeulen, E., Maertens, J., Meersseman, P., Saegeman, V., Dupont, L., and Lagrou, K. (2014). Invasive Aspergillus niger complex infections in a Belgian tertiary care hospital. Clinical microbiology and infection: the official publication of the European Society of Clinical Microbiology and Infectious Diseases, 20(5), O333-O335.

Viegas, C., Moreira, R., Faria, T., Caetano, L. A., Carolino, E., Gomes, A. Q., and Viegas, S. (2018). Aspergillus prevalence in air conditioning filters from vehicles: Taxis for patient transportation, forklifts, and personal vehicles. Archives of environmental and occupational health, $1-9$.

Vieira, M. R., Milheiro, A., and Pacheco, F. A. (2001). Phaeohyphomycosis due to Cladosporium cladosporioides. Medical mycology: official publication of the International Society for Human and Animal Mycology, 39(1), 135-137.

Visagie, C. M., Houbraken, J., Frisvad, J. C., Hong, S.-B., Klaassen, C. H. W., Perrone, G., et al., (2014). Identification and nomenclature of the genus Penicillium. Studies in mycology, 78, 343-371.

Wanner, H. U., Verhoff, A., and Colombi, A. (1994). Biological particles in indoor environments. European Collaborative Action "Indoor air quality and its impact on man". Commission of the European Communities (No. 12).

Weryszko-Chmielewska, E., Kasprzyk, I., Nowak, M., Sulborska, A., Kaczmarek, J., Szymanska, A., et al., (2018). Health hazards related to conidia of Cladosporium-biological air pollutants in 
Poland, central Europe. Journal of environmental sciences, 65, 271-281.

Wolkoff, P. (2018). Indoor air humidity, air quality, and health - An overview. International journal of hygiene and environmental health, 221(3), 376-390.

WORLD HEALTH ORGANIZATION (WHO). (1988). Indoor air quality: Biological contaminants. Copenhagen, Denmark: World Health Organization.

WORLD HEALTH ORGANIZATION (WHO). (2009). Dampness and Mould - WHO Guidelines for Indoor Air Quality. World Health Organization Regional Office for Europe, Geneva.

WORLD HEALTH ORGANIZATION (WHO). (2010). WHO guidelines for indoor air quality: selected pollutants. World Health Organization Regional Office for Europe, Copenhagen.

Woudenberg, J. H. C., van der Merwe, N. A., Jurjević, Ž., Groenewald, J. Z., and Crous, P. W. (2015). Diversity and movement of indoor Alternaria alternata across the mainland USA. Fungal genetics and biology: FG and B, 81, 6272.

Yu, X., Cai, X., Xu, X., Zhang, L., Huang, X., Wang, L., and Chen, Y. (2018). Fungemia caused by Penicillium marneffei in an immunocompetent patient with COPD. Medicine, 97(3), e9658.

Ziehe, É. M., Fernandes, R. B., Macedo, M. R. V., Vieira, V. M., and de Moraes, A. M. L. (2014). Determinação da contaminação fúngica do ar em Creches Públicas do Rio de Janeiro/RJ. Vigilância Sanitária em Debate, 2(1). doi:10.3395/vd.v2i1.96

Zoppas, B. C. A., Valencia-Barrera, R. M., and Fernandez-Gonzales, D. (2011). Cladosporium spp spores distribution in the atmospheric air of Caxias do Sul-RS, Brazil, during a two-year study. Revista Brasileira de Alergia e Imunopatologia, 34(2), 55-58.

Zubairi, A. B. S., Azam, I., Awan, S., Zafar, A., and Imam, A. A. (2014). Association of airborne Aspergillus with asthma exacerbation in Southern Pakistan. Asia Pacific allergy, 4(2), 91-98.

\section{How to cite this article:}

Jean Phellipe Marques do Nascimento, Ana Maria Queijeiro López, Mykaella Andrade de Araújo, Lucas Anhezini de Araujo and Eurípedes Alves da Silva Filho. 2019. Airborne Fungi in Indoor Hospital Environments. Int.J.Curr.Microbiol.App.Sci. 8(01): 2749-2772. doi: https://doi.org/10.20546/ijcmas.2019.801.291 